Research Article

\title{
Farmers' Practices in Using Insecticides to Control Spodoptera exigua Infesting Shallot Allium cepa var. aggregatum in the Shallot Production Centers of Java
}

\author{
Gracia Melsiana Aldini'), Y. Andi Trisyono ${ }^{1) *}$, Arman Wijonarko'), Witjaksono' ${ }^{1)}$, \& Herman de Putter $^{2)}$ \\ ${ }^{1)}$ Department of Plant Protection, Faculty of Agriculture, Universitas Gadjah Mada \\ Jln. Flora No. 1, Bulaksumur, Sleman, Yogyakarta 55281 \\ ${ }^{2)}$ Field Crops, Wageningen University \& Research, Wageningen \\ P.O. Box 430, 8200 AK, Lelystad, Netherlands \\ *Corresponding author.E-mail: anditrisyono@ugm.ac.id
}

Received July 22, 2019; revised January 16, 2020; accepted January 27, 2020

\begin{abstract}
The beet armyworm, Spodoptera exigua Hübn. (Lepidoptera: Noctuidae) is a major insect pest of shallot in Java. This research was aimed to determine how insecticides were used as the common farmers practice for controlling $S$. exigua. The research was conducted in three shallot production centers in Java: the Districts of Brebes (Central Java Province), Nganjuk (East Java Province), and Bantul (the Special Region of Yogyakarta). Surveys were conducted by interviewing thirty shallot farmers as respondents from each district. The selected thirty farmers were taken from four sub-districts. Almost all farmers (93.3\%) in the three districts had similar perception that S. exigua was the major insect pest in shallot and $84.4 \%$ farmers stated that this insect was difficult to control. The four most common insecticides active ingredients used were chlorfenapyr, methomyl, chlorpyrifos, and emamectin benzoate. Insecticides remained the first choice and they were applied throughout the shallot season mostly based on the calendar (1-3 days interval). When using insecticides farmers tend to exceed the label recommended rates, and the farmers mostly mixed different insecticides into one spray solution. These results suggest that application of insecticides to control S. exigua was already exessive. The potential risks and efforts essential to minimize the risks are discussed.
\end{abstract}

Keywords: beet armyworm Spodoptera exigua; insecticide misuse; Java; shallot

\section{INTRODUCTION}

The beet armyworm, Spodoptera exigua Hübn. (Lepidoptera: Noctuidae) is a major pest in shallot producing areas and is widely spread in Indonesia (CIE, 1972; Rauf, 1999). S. exigua could cause yield loss ranging from 57 to $100 \%$ without control measures (Ministry of Agriculture, 1992; Rauf, 1999). Shallot farmers in Java rely heavily on insecticides to combat this insect (Trisyono \& Untung, 2008, unpublished). Similarly, this insect has become more damaging in China since 1980, and insecticides have been intensively used by the farmers to control S. exigua (Zhang et al., 2014).

The improper use of insecticides may cause environmental pollution, resurgence, resistance, and may kill non-target organisms (Metcalf, 1986). Although the newer insecticides are considered more selective and more environmentally friendly than the three most commonly used insecticide groups in the past (carbamate, organophosphate, and pyrethroid) (Koster, 1990), misuse of those insecticides may be detrimental to the environment. One of the most common riks of excessive use of insecticides is the development of resistance on the target insect. The development of resistance to different insecticides (chlorpyrifos, beta-cyfluthrin, cyromazine, carbosulfan, and abamectin) has been previously reported in Indonesia (Moekasan, 1998; Moekasan \& Basuki, 2007; Basuki, 2009). Several studies showed that the field populations of S.exigua has developed resistance to insecticides in other countries (Osorio et al., 2008; Ahmad \& Arif, 2010; Istiaq et al., 2012; Che et al., 2013; Ahmad et al., 2018; Wang et al., 2018; Saeed et al., 2019). The populations of this insect in Indonesia, the United States, Thailand, Pakistan and China have become resistant to a relatively new insecticide group of non-steroidal ecdysone agonists such as tebufenozide and methoxyfenozide (Moulton et al., 2002; Wibisono et al., 2007; Osorio et al., 2008; Istiaq et al., 2012; Che et al., 2013). 
Insecticides registered in Indonesia to control $S$. exigua showed an annual increase. In 2016-2018, the number of trade names increased from 254 to 267 but the number of active ingredients decreased for the same period of time, from 67 in 2016 to 59 in 2018. (Ministry of Agriculture, 2013; 2014; 2016; 2018). These suggest that the same active ingredient was reregistered with more trade names. Farmers rely on the advices from their colleagues and agro shop dealers for the choice of pesticide to use against $S$. exigua (Basuki, 2009). This study was aimed to determine which insecticides were the mostly used by shallot farmers to control S. exigua in the shallot production centers in the Districts of Nganjuk, Bantul and Brebes. The findings will be useful to establish further researches on the development of resistance and its management as well as to develop policies to minimize the risks.

\section{MATERIALS AND METHODS}

\section{Location}

Data collection was carried out by a survey method involving 90 shallot farmers in Java from June to August 2018. The total sample was taken from three districts of shallot production centers: Brebes-Central Java, Nganjuk-East Java, BantulYogyakarta, each of 30 farmers respectively. The farmers selected as respondents were from four subdistricts in Brebes (Songgom, Wanasari, Larangan, and Brebes) and Nganjuk (Bagor, Rejoso, Sukomoro, and Wilangan), and only three from Bantul (Sanden, Kretek, and Pundong). The selected sub-districts were shallot production areas in each district. The selected farmers were those who have had experience of planting shallot for a minimum of five years.

The research was conducted by employing a quantitative descriptive method based on survey. Data was collected through individual interview using a questionnaire consisting of closed questions (multiple choices), open-ended questions, and a combination of open and closed questions (Creswell, 2014). The questionnaire used during the survey covered three major aspects: the perception of farmers in regard with the economic importance of S.exigua; the insecticides commonly used by farmers to control S. exigua, and the common farmer practices in using insecticides. Data was analyzed using the descriptive technique

\section{RESULTS AND DISCUSSION}

\section{The Importance of S. exigua}

$S$. exigua and $S$. litura were the major pests infesting shallot in the three districts Brebes, Nganjuk, and Bantul. Among the two Spodoptera species, most farmers $(93.3 \%)$ thought that $S$. exigua was more damaging to the shallot than that of S. litura $(6.7 \%)$ because of its difficulty to control $(84.4 \%)$ (Table 1$)$. The larvae live inside the cylindrical leaves that give them more protection. In addition, the development of resistance may result in failure in control if insecticides are not appropriately used (Wibisono et al., 2007; Osorio et al., 2008; Ahmad \& Arif, 2010; Istiaq et al., 2012; Che et al., 2013; Ahmad et al., 2018; Wang et al., 2018; Saeed et al., 2019). Generally, the farmers identified $S$. exigua based on the colors of larvae. Although the larvae of $S$. exigua are polymorphic, the farmers were able to distinguish between the two species of Spodoptera when pictures were shown to the farmers. During high population, $80 \%$ of the fifth instars' colour are dark. In contrast, $90 \%$ of the larvae's colour are bright green when the population was low (Rauf, 1999).

\section{Commonly Used Insecticides to Control S. exigua}

To control S. exigua, the first control measure was taken at 10-15 days after planting (dap), and $84.4 \%$ of the farmers chose to control them with insecticide(s). During the planting season, $73.3 \%$ of the farmers used a combination of insecticides and mechanical control by hand picking. In addition, light traps were employed by $6.7 \%$ of the farmers

Table 1. Farmers' perception on major insect pests infesting shallot in the centers of growing areas in Java

\begin{tabular}{|c|c|c|c|c|}
\hline \multirow{2}{*}{$\begin{array}{c}\text { Based on the type } \\
\text { of pest }\end{array}$} & \multicolumn{3}{|c|}{ Number of farmers $(\%)^{*}$} & \multirow[t]{2}{*}{ Mean } \\
\hline & Brebe & ganjuk & Bantul & \\
\hline \multicolumn{5}{|l|}{ Incidence } \\
\hline a. Spodoptera exigua & 90.0 & 93.3 & 96.7 & 93.3 \\
\hline b. Spodoptera litura & 10.0 & 6.7 & 3.3 & 6.7 \\
\hline \multicolumn{5}{|c|}{ Based on the difficultly in control } \\
\hline a. Spodoptera exigua & 86.7 & 70.0 & 96.7 & 84.4 \\
\hline b. Spodoptera litura & 13.3 & 30.0 & 3.3 & 15.6 \\
\hline
\end{tabular}


in Brebes but none in the other two locations. Most farmers $(90 \%)$ in Brebes and Nganjuk stopped using insecticides between 1 to 5 days before harvest; while most farmers in Bantul (73.3\%) stopped using insecticides earlier ( $>6$ days before harvesting) (Table 2). This suggests that some of the farmers in Bantul is more rational in using insecticides than those in Brebes and Nganjuk.

Overall, there were a total of 19 insecticides' active ingredients (a.i.) consisting of 14 single a.i. and five mixtures of two a.i. that have been used to control S. exigua by the farmers in three districts (Table 3). These 19 a.i. fell into 12 different mode of actions (MoA) based on Insecticide Resistance Action Committee (IRAC) classification (IRAC, 2019). The number of a.i. used by farmers among the three districts varied from nine in Bantul to 14 in Brebes. However, there were four insecticides commonly used by the farmers in all districts, namely chlorfenapyr, methomyl, chlorpyrifos, and emamectin benzoate. Among these four, chlorfenapyr was the most widely selected and used by the shallot growers. All farmers in Brebes used chlorfenapyr (100\%), and the same insecticide was used by $93.3 \%$ farmers in Nganjuk, and $34.8 \%$ in Bantul. Methomyl was the second mostly used for controlling S. exigua; while chlorpyrifos and emamectin benzoate were very much similar in term of the number of farmers used these two insecticides.
A total of 29 commercially formulated products with different trade-names are available for chlorfenapyr and the same number also apply for chlorpyrifos, but in terms of trade names' number for the same a.i. they are second to cypermethrin with 35 trade names (Ministry of Agriculture, 2018). A total of 17 different formulated commercial products based on 14 different a.i. were used by the farmers in Brebes for controlling S. exigua, while in Nganjuk this was 27 trade names with 13 a.i.; and 16 trade names with 9 a.i. in Bantul. These data suggest that the farmers tend to apply the same trade name for the same a.i. even though there are many other trade names with similar a.i. The use of the same trade name or different trade names but similar a.i. over a period of time would increase the risk of resistance development in S. exigua. Furthermore, the 267 trade names with 59 a.i. registered for this insect (Ministry of Agriculture, 2018) pose additional issues related to the implementation of insect resistance management (IRM) principles. For example, we found that selection of insecticides was not necceserely based on the intention to rotate the different MoA but was mostly driven by promotional insecticide sales $(23.3 \%)$ and recommendation from other farmers $(41.1 \%)$ based on the trade names.

The four mostly used insecticides mentioned above are all broad spectrum insecticides targeting

Table 2. Control measures practiced by farmers in the centers shallot producing areas in Java

\begin{tabular}{|c|c|c|c|c|}
\hline \multirow{2}{*}{ Control technique and timing } & \multicolumn{3}{|c|}{ Number of farmers $(\%)^{*}$} & \multirow{2}{*}{ Mear } \\
\hline & Brebes & Nganjuk & Bantul & \\
\hline \multicolumn{5}{|l|}{ A. Early stage } \\
\hline \multicolumn{5}{|l|}{ 1. First control (days after planting) } \\
\hline a. $1-5$ & 3.3 & 10.0 & & 4.4 \\
\hline b. $6-9$ & 16.7 & 36.7 & 20.0 & 24.4 \\
\hline c. $10-15$ & 73.3 & 53.3 & 63.3 & 63.3 \\
\hline d. $16-20$ & 6.7 & & 16.7 & 7.8 \\
\hline \multicolumn{5}{|l|}{ 2. Control technique } \\
\hline a. Insecticides & 83.3 & 90.0 & 80.0 & 84.4 \\
\hline b. Mechanical & 16.7 & 10.0 & 20.0 & 15.6 \\
\hline \multicolumn{5}{|c|}{ B. Control technique used during the plant growth } \\
\hline 1. Using insecticide only & 10.0 & 33.3 & 26.7 & 23.3 \\
\hline 2. Insecticide and mechanical & 83.3 & 63.3 & 73.3 & 73.3 \\
\hline 3. Light trap & 6.7 & & 2.2 & \\
\hline 4. Insecticide, mechanical and glue & 3.3 & 1.1 & & \\
\hline \multicolumn{5}{|c|}{ C. Last insecticide application (days before harvesting) } \\
\hline 1. $1-5$ & 90.0 & 90.0 & 26.7 & 68.9 \\
\hline 2. $6-10$ & 6.7 & 10.0 & 53.3 & 23.3 \\
\hline 3. $>10$ & 3.3 & & 20.0 & 7.8 \\
\hline
\end{tabular}

Remark: *Number of farmers interviewed was thirty in each district 
Table 3. Active ingredients of insecticides commonly used by farmers in the center of shallot producing areas in Java

\begin{tabular}{|c|c|c|c|c|c|}
\hline \multirow[t]{2}{*}{ No. } & \multirow{2}{*}{$\begin{array}{l}\text { Active Ingredient of formulated product } \\
\text { used }\end{array}$} & \multirow{2}{*}{$\begin{array}{l}\text { MoA } \\
\text { group* }\end{array}$} & \multicolumn{3}{|c|}{ Number of farmers $(\%)^{* *}$} \\
\hline & & & Brebes & Nganjuk & Bantul \\
\hline 1 & chlorfenapyr & 13 & 100.0 & 93.3 & 34.8 \\
\hline 2 & methomyl & $1 \mathrm{~A}$ & 26.7 & 56.7 & 8.9 \\
\hline 3 & chlorpyrifos & 1B & 20.0 & 10.0 & 4.4 \\
\hline 4 & emamectin benzoate & 6 & 13.3 & 26.3 & 13.0 \\
\hline 5 & spinetoram + methoxyfenozide $* * *$ & $5+18$ & 33.3 & 13.3 & \\
\hline 6 & emamectin benzoate + chlorbenzuron*** & $6+15$ & 26.7 & 16.7 & \\
\hline 7 & triazophos & 1B & 3.3 & 36.7 & \\
\hline 8 & cyantraniliprole & 28 & 10.0 & 16.7 & \\
\hline 9 & indoxacarb+emamectin benzoate*** & $22 \mathrm{~A}+6$ & 6.7 & 13.3 & \\
\hline 10 & abamectin & 6 & 6.7 & 10.0 & \\
\hline 11 & cyromazine & 17 & 6.7 & & \\
\hline 12 & chlorfluazuron & 15 & 3.3 & & \\
\hline 13 & chlorantraniliprole+thiamethoxam*** & $28+4 \mathrm{~A}$ & 3.3 & & \\
\hline 14 & thiodicarb & $1 \mathrm{~A}$ & 6.7 & & 21.7 \\
\hline 15 & chlorpyrifos-methyl & 1B & & 3.3 & \\
\hline 16 & chlorpyrifos + cypermethrin $* * *$ & $1 \mathrm{~B}+3 \mathrm{~A}$ & & 16.7 & 21.7 \\
\hline 17 & beta-cyfluthrin & $3 \mathrm{~A}$ & & 3.3 & 30.4 \\
\hline 18 & chlorantraniliprole & 28 & & & 29.1 \\
\hline 19 & profenofos & 1B & & & 13.1 \\
\hline
\end{tabular}

Remarks: * Mode of Action (MoA) group was based on Insecticide Resistance Action Committee (IRAC, 2019)

** Number of farmers interviewed was thirty in each district and each number represent the proportion of farmers used a particular a.i.

*** Two active ingredients in one formulation

different sites. Methomyl (carbamate group) and chlorpyrifos (organophosphate group) inhibit acetylcholinesterase (AChE), a neuroreceptor catalyst. Chlorfenapyr (pyrroles group) disrupts the respiratory pathway and the proton gradient through the termination of oxidative phosphorylation in mitochondria, and emamectin benzoate (avermectin group) activates channels of chloride glutamate-gated glutamate (GluCls) caused paralysis in insects (IRAC, 2019). In addition to the risk of resistance development due to lack of rotation with different MoA, the use of broad spectrum insecticides could be detrimental to the natural enemies of $S$. exigua which potentially facilitate the outbreak due to lack of the population regulating factors.

\section{Application of Insecticides}

All farmers in Brebes and Nganjuk applied insecticides to control S.exigua based on the calendar bases with an interval of 1-3 days with a 2-day interval as the most preferrable. In Bantul, some farmers $(13.3 \%)$ used insecticides only when the population of this insect was considerably high which might cause some economic losses. Most farmers $(58.9 \%)$ used the same insecticide for the whole season (Table 4). Most farmers in all districts $(80 \%)$ practiced improper use of insecticides by applying either lower or higher dosages than the label recommended rates (Table 5). Moreover, most farmers in these districts mixed 2-5 formulated products in one spray solution with the reason for reducing the

Table 4. Interval and rotation of insecticide applications practiced by farmers in the centers of shallot producing areas in Java

\begin{tabular}{|c|c|c|c|c|}
\hline \multirow{2}{*}{$\begin{array}{c}\text { Interval } \\
\text { Insecticide } \\
\text { application }\end{array}$} & \multicolumn{3}{|c|}{ Number of farmers $(\%)^{*}$} & \multirow[t]{2}{*}{ Mean } \\
\hline & Brebes & Nganjuk & Bantul & \\
\hline $\begin{array}{l}\text { A. 1. Routine } \\
\text { (calendar) }\end{array}$ & 100.0 & 100.0 & 86.7 & 95.6 \\
\hline a. Daily & 30.0 & 40.0 & 15.4 & 29.1 \\
\hline b. Two & 46.7 & 60.0 & 38.5 & 48.8 \\
\hline c. Three & 20.0 & & 38.5 & 17.8 \\
\hline d. Four & 3.3 & & 7.7 & 3.3 \\
\hline e. Five & & 3.8 & 1.1 & \\
\hline $\begin{array}{l}\text { 2. Conditional } \\
\text { (observing) }\end{array}$ & & & 13.3 & 4.4 \\
\hline \multicolumn{5}{|c|}{ B. Rotation of product } \\
\hline 1. With rotation & 63.3 & 63.3 & 50.0 & 58.9 \\
\hline 2. No rotation & 36.7 & 36.7 & 50.0 & 41.1 \\
\hline
\end{tabular}

Remark: *Number of farmers interviewed was thirty in each district 
costs of labor and they thought that mixing several insecticides provided more effectiveness in controlling S. exigua (Table 6).

The above findings suggest that insecticides misuse is a common practice by farmers in the shallot producing area in Java and it is a serious issue. Mixing several a.i. without knowing their compatibility would increase the risk of resistance to several a.i. at the same time (Brown 1958). De Putter et al., (2017) reported that farmers believed that mixing profenofos, lambda-cyhalothrin, and chlorantraniliprole would give a better control to $S$. exigua than using only a single a.i. Unfortunately, $63 \%$ of the farmers did not have sufficient knowledge about the resistance development and the risks of insecticides misuse.

In Indonesia, the resistance in the populations of $S$. exigua to a number of insecticides has been previously reported. Moekasan \& Basuki (2007) found that $S$. exigua populations in Brebes was resistant to

Table 5. Concentration of insecticides used to control Spodoptera exigua by farmers in the centers of shallot producing areas in Java

\begin{tabular}{|c|c|c|c|c|}
\hline \multirow{2}{*}{$\begin{array}{l}\text { Compared to } \\
\text { the recommended } \\
\text { concentration }\end{array}$} & \multicolumn{3}{|c|}{$\begin{array}{c}\text { Number of } \\
\text { farmers }(\%)^{*}\end{array}$} & \multirow[t]{2}{*}{ Mean } \\
\hline & Brebes & Iganju & $\overline{\text { Bantul }}$ & \\
\hline Less $(<1 \mathrm{x})$ & 16.7 & 6.7 & 23.3 & 15.6 \\
\hline $\begin{array}{l}\text { At the } \\
\text { recommendation }(1 \mathrm{x})\end{array}$ & 3.3 & 16.7 & 40.0 & 20.0 \\
\hline Higher $(1.25 \mathrm{x})$ & 20.0 & 13.3 & 23.3 & 18.9 \\
\hline Excessive $(1.5 x)$ & 43.3 & 30.0 & 10.0 & 27.8 \\
\hline Highly excessive (2.0x) & 16.7 & 33.3 & 3.3 & 17.8 \\
\hline
\end{tabular}

Remark: *Number of farmers interviewed was thirty in each district

Table 6. Farmers' practice of insecticide mixing in one tank to control Spodoptera exigua in the centers of shallot producing areas in Java

\begin{tabular}{|c|c|c|c|c|}
\hline \multirow{2}{*}{$\begin{array}{l}\text { No. active } \\
\text { ingredients }\end{array}$} & \multicolumn{3}{|c|}{ Number of farmers $(\%)^{*}$} & \multirow{2}{*}{ Mean } \\
\hline & Brebes & Nganjuk & Bantul & \\
\hline A. Single & 13.3 & 13.3 & 26.7 & 17.8 \\
\hline B. Mixture & 86.7 & 86.7 & 73.3 & 82.2 \\
\hline 1. Two & 3.8 & 23.1 & 72.7 & 31.1 \\
\hline 2. Three & 30.7 & 57.7 & 22.7 & 37.8 \\
\hline 3. Four & 30.7 & 11.5 & 4.6 & 16.2 \\
\hline 4. Five & 34.7 & 3.8 & & 13.5 \\
\hline
\end{tabular}

Remark: *Number of farmers interviewed was thirty in each district chlorpyrifos and beta-cyfluthrin. Resistance to nonsteroidal ecdysone agonist methoxyfenozide was found in field populations collected from Brebes and Nganjuk (Wibisono et al., 2007). In Pakistan, S. exigua was resistant to indoxacarb, spinosad, chlorfenapyr, abamectin, and emamectin benzoate (Ahmad et al., 2018). These reports indicate that $S$. exigua has been able to develop resistance to different insecticides with different MoA. The resistance of pest to insecticides is characterized by a decrease in the insecticide efficacy (Gould, 1984; Lockwood et al., 1984). As a result, the farmers often increase dosages, shorten the application frequency, and mix insecticides with the expectation to have an improved control. This approach is not likely to solve the problem, but it may even increase the intensity and diversity of the problems posed by high rate of insecticides, such as the development of resistance and reduced role of beneficial organisms in regulating the population of S. exigua.

\section{CONCLUSION}

The farmers in the shallot production centers districts in Java (Brebes, Nganjuk, and Bantul) perceived that $S$. exigua was the most important pest in shallot, and they relied on the use of insecticides for controlling this insect. The four most commonly used insecticides were chlorfenapyr, methomyl, chlorpyrifos, and emamectin benzoate which were commonly applied on calendar bases with a 2-day interval. In practice farmer used 2-5 formulated products in one spray solution with limited rotation of a.i., and the exessive rate was often applied. Extension and education on the proper use of insecticides are essential and should be considered as an immediate need for the reduced risks in $S$. exigua control program.

\section{ACKNOWLEDGEMENTS}

We would like to thank vegIMPACT NL funded by the Government of the Netherlands and coordinated by Wageningen University \& Research for the partial funding to the project; and Lutfi Arifin, Dadya Adi, and Candya Putra for assisting in the data collection. This article is part of first author's master thesis. 


\section{LITERATURE CITED}

Ahmad, M. \& M.I. Arif. 2010. Resistance of Beet Armyworm Spodoptera exigua (Lepidoptera: Noctuidae) to Endosulfan, Organophosphorus and Pyrethroid Insecticides in Pakistan. Crop Protection 29: 1428-1433.

Ahmad, M., A. Farid, \& M. Saeed. 2018. Resistance to New Insecticides and their Synergism in Spodoptera exigua (Lepidoptera: Noctuidae) From Pakistan. Crop Protection 107: 79-86.

Basuki, R.S. 2009. Farmers' Knowledge and the Effectiveness of Insecticide-use Practiced by Farmers to Control Spodoptera exigua on Shallots in Brebes and Cirebon. Jurnal Hortikultura 19: 459-474.

Brown, A.W.A. 1958. Insecticide Resistance in Arthopods. WHO, Geneva. 240 p.

Che, W., T. Shi, Y. Wu, \& Y. Yang. 2013. Insecticide Resistance Status of Field Populations of Spodoptera exigua (Lepidoptera: Noctuidae) From China. Journal of Economic Entomology 106: $1855-1862$.

CIE. 1972. Distribution Maps of Pests. Map No. 302. Commonwealth Institute of Entomology, London, United Kingdom.

Creswell, J.W. 2014. Research Design: Qualitative, Quantitative, and Mixed Methods Approaches. Fourth Edition. SAGE Publications Ltd., California. $342 \mathrm{p}$.

DePutter, H., W. Adiyoga, \& J. Sugiharto. 2017. Effect of Pesticide Mixing on Control of Anthracnose and Spodoptera exigua in Shallot. VegIMPACT Report 38. Wageningen University $\&$ Research, The Netherlands.

Georghiou, G.P. 1972. The Evaluation of Resistance of Pesticides. Annual Review of Ecology, and Systematics 3: 133-168.

Gould, F. 1984. Role of Behavior in the Evolution of Insect Adaptation to Insecticides and Resistance Host Plants. Entomological Society of America 30: 34-40.

IRAC. 2019. The IRAC Mode of Action Classification. https://www.irac-online.org/modes-of-action, modified 01/04/2019.
Ishtiaq, M., M. A. Saleem, \& M. Razaq. 2012. Monitoring of Resistance in Spodoptera exigua (Lepidoptera: Noctuidae) From Four Districts of the Southern Punjab, Pakistan to Four Conventional and Six New Chemistry Insecticides. Crop Protection 33: 13-20.

Ministry of Agriculture (Kementerian Pertanian). 1992. Pedoman Pengenalan dan Pengendalian Hama Bawang Merah. Direktorat Perlindungan Tanaman. Direktorat Jenderal Pertanian Tanaman Pangan Kementerian Pertanian Republik Indonesia, Jakarta. 21 p.

Ministry of Agriculture (Kementerian Pertanian). 2013. Pestisida Pertanian dan Kehutanan. Pusat Perizinan dan Investasi Sekretariat Jenderal Kementerian Pertanian Republik Indonesia, Jakarta. $682 \mathrm{p}$.

Ministry of Agriculture (Kementerian Pertanian). 2014. Pestisida Pertanian dan Kehutanan. Pusat Perizinan dan Investasi Sekretariat Jenderal Kementerian Pertanian Republik Indonesia, Jakarta. $1002 \mathrm{p}$.

Ministry of Agriculture (Kementerian Pertanian). 2016. Pestisida Pertanian dan Kehutanan. Direktorat Jenderal Prasarana dan Sarana Pertanian Kementerian Pertanian Republik Indonesia, Jakarta. 1096 p.

Ministry of Agriculture (Kementerian Pertanian). 2018. Sistem Informasi Pestisida. http://pestisida.id/ simpes_app/rekap_kimia_formula.php., modified 18/12/2018.

Koster, W.G. 1990. Exploratory Survey on: Shallot in Rice-Based Cropping Systems in Brebes. Buletin Penelitian Hortikultura 18: 19-30.

Lockwood, J.A., T.C. Sparks, \& R.N. Story. 1984. Evolution of Insect Resistance to Insecticides: A Revelation of the Role of Physiology and Behavior. Entomological Society of America 30: 41-51.

Metcalf, R.L. 1986. The Ecology of Insecticides and the Chemical Control of Insect, p. 251-294. In M. Kogan (ed.), Ecological Theory and Integrated Pest Management Practice. John Wiley \& Son, New York.

Moekasan, T.K. \& R.S. Basuki. 2007. Resistance Status of Spodoptera exigua Hubn. on Shallot 
from Cirebon, Brebes, and Tegal District to Several Insecticide Commonly Used by Farmers. Jurnal Hortikultura 17: 343-354.

Moekasan, T.K. 1998. Status Resistensi Ulat Bawang Spodoptera exigua Hübn. Strain Brebes terhadap Beberapa Jenis Insektisida. Jurnal Hortikultura 7: 913-918.

Moulton, J.K., D.A. Pepper, R.K. Jansson, \& T.J. Dennehy. 2002. Pro-active Management of Beet Armyworm (Lepidoptera: Noctuidae) Resistance to Tebufenozide and Methoxyfenozide: Baseline Monitoring, Risk Assessment and Isolation of Resistance. Journal of Economic Entomology 95: 414-424.

Osorio, A., A. M. Martínez, M. I. Schneider, O. Díaz, J.L. Corrales, M. C. Avilés, G. Smagghe, \& S. Pineda. 2008. Monitoring of Beet Armyworm Resistance to Spinosad and Methoxyfenozide in Mexico. Pest Management Science 64: 1001-1007.

Rauf, A. 1999. Population Dynamics of Spodoptera exigua Hübn. (Lepidoptera: Noctuidae) on Shallot Fielsd in Low-Land. Buletin Hama dan Penyakit Tumbuhan 11: 39-47.

Saeed, Q., F. Ahmad, N. Iqbal, \& S.M. Zaka. 2019. Chemical Control of Polyphagous Pests on their
Auxiliary Hosts Can Minimize Insecticide Resistance: A Case Study of Spodoptera exigua Hübner (Lepidoptera: Noctuidae) in Cotton Agroecosystem Ecotoxicology and Environmental Safety 171: 721-727.

Ullah, S., R. M. Shah, \& S. A. Shad. 2016. Genetics, Realized Heritability and Possible Mechanism of Chlorfenapyr Resistance in Oxycarenus hyalinipennis (Lygaeidae: Hemiptera). Pesticide Biochemistry and Physiology 133: 91-96.

Wang, X., X. Xiang, H. Yu, S. Liu, Y. Yin., P. Cui, Y. Wu, J. Yang, C. Jiang, \& Q. Yang. 2018. Monitoring and Biochemical Characterization of Beta-cypermethrin Resistance in Spodoptera exigua (Lepidoptera: Noctuidae) in Sichuan Province, China. Pesticide Biochemistry and Physiology 146: 71-79.

Wibisono, I. I., Y. A. Trisyono, \& E. Martono. 2007. Field Evaluation of Resistance to Methoxyfenozide in Spodoptera exigua in Java. Jurnal Perlindungan Tanaman Indonesia 13: 127-135.

Zhang, P., M. Gao, W. Mu, C. Zhou, \& X.H. Li. 2014. Resistant Levels of Spodoptera exigua to Eight Various Insecticides in Shandong, China. Journal of Pesticide Science 39: 7-13. 